\title{
Public Participation and the Disclosure of Public Information to Achieve Good Governance
}

\author{
Muhammad Raji Fudin' ${ }^{1}$, Annisa Maharani Rahayu ${ }^{2}$ \\ \{mrajifudin@gmail.com ${ }^{1}$, a.maharani2327@gmail.com ${ }^{2}$ \} \\ Universitas Negeri Semarang, Indonesia ${ }^{1,2}$ \\ Balairung Network + , Indonesia ${ }^{1,2}$
}

\begin{abstract}
Public participation is one of the important elements in a democratic country. Participation should be present in every policy making process carried out by the government. The absence of participation makes a policy vulnerable to rejection. In the case of top-down policies, participation does not originate from the society affected by policies but from the government, in other words policies tend to be Government-centric. Rejection can be minimized by information disclosure from the government, before the policy is passed. This study uses a literature review method that is relevant to the topic of discussion, as well as observation. Information disclosure will make the community have an initial understanding of policy. Information disclosure will affect participation, with the main goal of realizing good governance.
\end{abstract}

Keywords: Good Governance, Information Disclosure, and Participation

\section{Introduction}

Nowadays, we have entered the era of globalization, namely an era where all boundaries between countries are erased because technology and information stream are growing rapidly [1][2][3]. This rapidly growing stream of information and technology certainly has a positive and negative impact on society, one of the most prominent impacts of which is the increase in community participation in decision making or policy making in a country, and indirectly can create a good governance [4][5][6]. But in Indonesia, the community has not fully participated in improving the quality of existing government.

In this era of globalization, decision making or policy making is still top-down, even though the channels to absorb aspirations in participation are so many. A bottom-up policy or policy that comes from community participation is important to do. Because the meaning of participation is seen from the political side not only in accepting and rejecting government policy designs, but also proposing a policy. Community participation is community participation in all government activities in order to obtain information and be able to participate in building their country. In addition, participation is one of the rights of the community [7] which has been guaranteed in statutory provisions. So that indirectly with the existence of community participation in policy making or decision making, the community is taught to be more responsible in building their country. 
On the other hand, globalization also has an impact on the exposure of information stream. Information obtained is not only about popular global issues, but also about public information. Public information itself is information that is managed, disseminated, produced, received, and produced by a public body (Law No. 14 of 2008 concerning Freedom of Public Information). Even so, there are still many government circles that do not yet have an awareness of public information disclosure, including Indonesia. In Indonesia there are still many government structures that are not yet open. Even though opening information is a form of accountability from the government to the community.

As explained earlier that community participation and information disclosure will create a good governance, so the author in this study put forward a research question, namely: How can public participation and public disclosure of information create a good governance?

\section{Research Methodology}

The method used in this research is library research, series of studies whose objects are explored through various library information. The focus of literature reviews to find various theories that are used to analyze and solve research questions formulated. The focus of the discussion on this paper will lead to theories of public participation, good governance, and information disclosure, with data sources in the form of books, scientific articles, and relevant legislation.

\section{Findings and Discussion}

\subsection{Good Governance}

The concept of government or governance has developed before entering the era of globalization as it is today. The concept of governance itself has existed since the beginning of 1990 which was marked by the development of a viewpoint on the government or government in running the government [8]. Then the concept of governance developed along with the emergence of globalization so that a concept that was called good governance was born. Good governance appears to run a government that upholds the values of the people, enhances the ability of the people to achieve an independent and fair state development, and creates a government that is solid, responsible, efficient, effective, and can have integrity with the public and the private sector.

Good governance has several principles, including; First, community participation [9]. All community members have a voice in decision making, both directly and through representative institutions. Overall participation is built on freedom of assembly and expression of opinion, and the capacity to participate constructively.

Second, the establishment of the rule of law. The legal framework must be fair and enforced indiscriminately, including laws relating to human rights. Third, there is a transparency. Transparency is built on the free stream of information. All government processes, institutions and information must be easily accessed by interested parties, and the available information must be sufficient to be easily understood and monitored.

Fourth, caring for stakeholders. Institutions and the entire government process must try to serve all interested parties. Fifth, consensus oriented. Good governance bridges a variety of 
different interests in order to establish a comprehensive consensus in the best case for civil society groups that are good, and if possible, consensus in terms of policies and procedures. Sixth, the equality of all community. Communities have the opportunity to improve or maintain their welfare. Then the Seventh, effectiveness and efficiency. Government processes produce results according to the needs of the community and by using the available resources as optimally as possible. Eighth, Accountability. Decision makers in the government, private sector and community organizations are responsible both to the community and to interested institutions [9].

\subsection{Public Participation}

Public participation as explained earlier is community participation in all government activities in order to obtain information about their country, in order to be able to participate in building their country, and is one of the rights owned by the community [7]. So that indirectly with the existence of community participation in policy making or decision making, the community is taught to be more responsible in building their country. Self-participation is one of the cores of democracy and good governance. Participation is formed because of consensus or mutual agreement.

Public participation is divided into three categories, namely public participation in politics, public participation in social affairs, and public participation as community [10]. In public participation in politics, people choose and vote for candidates or representatives who they believe can accommodate their wishes in the seat of government. Then in public participation in social, that is, society becomes one of the parts in making decisions or becoming a consultant in the development of a country. The main purpose of public participation in social is so that the community has an understanding of public policy and is one form of social mobilization. Whereas public participation as a community is direct public participation in decision making or decision making in government institutions and processes. This participation is oriented to the agenda of determining public policy. So that this participation makes the community the most important part or subject in forming a public policy agenda. Policy planning is prepared by the community, until the implementation of the policy, the community is included.

Participation, on the other hand, can be divided into two, namely autonomic participation and mobilization participation [11]. Autonomous participation arises from awareness, self-will and voluntary, while mobilization participation is participation that is driven or forced. Autonomous participation is the key to democracy and is a political right of community. Increasing community participation is not only focused on planning and evaluating policy programs, but the community must be able to integrate with development programs or policies implemented.

\subsection{Public Information Disclosure}

In the era of global competition, entities that can survive and take advantage of competition are entities that control as much information as possible [12]. This entity can be a country. The state in this case the government has a variety of information from various sources. This information if processed properly can be used to improve community welfare. However, information held by the government is information held by the community. Thus, the government needs to share that information with the public, so that information hegemony does not occur that could adversely affect the government. However, the state does not need to share 
all information it has, there is some information that does need to be kept secret or excluded from the public according to the principle of Maximum Access and Limited Exemption [13].

Indonesia regulates information disclosure through Law No. 14 of 2008 concerning Public Information Disclosure (UU KIP). Public information is information issued by public bodies. Public bodies can be said to be the main actors in information disclosure. Public bodies are executive, legislative, judicial, and other bodies whose functions and main tasks are related to state administration, in which part or all of their funds come from the APBN and / or APBD, or non-governmental organizations as long as part or all of their funds come from the APBN and / or APBD, donations from the community, and / or abroad. Information disclosure is a form of government responsibility to the community.

The right to obtain information is a human right that must be guaranteed by the state as civil and political rights. The consideration of UU KIP states that information is a basic requirement of every person. This refers to Article $28 \mathrm{~F}$ of the 1945 Constitution which states that "Every person has the right to communicate and obtain information to develop his personal and social environment, and has the right to seek, obtain, possess, store, process, and convey information using all types of available channels " This right is the basis for the community to be able to access the information needed, even save and use it.

Public information should be supply, in the sense that the community does not need to ask for information, the government has provided the information it has. Examples of the implementation of information disclosure can be seen every day with different channels, for example a road construction project that installs a board containing information on old work, costs, and project holders, or a government website that displays various information and activity reports. Some types of information that must be announced and excluded by public bodies can be seen in Law No. 14 of 2008 starting from Article 9 - Article 20.

\subsection{Information Disclosure and Participation}

Information disclosure has at least two positive impacts on its role in participation. First, the community participates in providing policy input to the government. Second, the community participates in overseeing the performance of public bodies. This correlates with the opinion that participation is an active and voluntary involvement that has various reasons, both intrinsic and extrinsic, in various kinds of process activities, such as decision making for supervision, evaluation, and utilization of the results of activities achieved [14].

First, the community participates in policy formulation. One of the objectives written in Law No. 14 of 2008 Article 3 letter "a" reads that this law "guarantees the right of citizens to know the plans for public policy making, public policy programs and the reasons for making a public decision". If at the beginning the policy discussion was made in a top-down manner by leaving the role of the community in providing input, then with information disclosure the public could still provide input before the policy was passed. In a simple sense the government must publish its policy plan, so that the public can provide input and then be processed by the government.

With open information, the input given by the community in policy formulation can be more substantial, because the public gets initial information first. This information then becomes the initial capital to provide input regarding policies. And this improves the quality of community participation.

Second, the public can oversee the performance of public bodies. The impact of information disclosure also benefits the government, because here the community participates in overseeing the performance of public bodies through information that is published. On the one hand, the community wants to better service public bodies, on the other hand the government is helped to 
oversee public bodies. Information obtained can be in the form of service standards provided by public bodies. With this information the community can provide assessments related to services and can provide input if the service does not meet the standards set. In addition, information that is open to opportunities for abuse of power in the form of KKN (Corruption, Collusion and Nepotism) can be avoided, because the public will continue to supervise all decisions made by the government.

\section{Conclusion}

Information disclosure is the right of every citizen and the obligation for the government as a form of accountability. Access to this information must pay attention to the type of information and channels chosen. Information disclosure carried out by public bodies intersects with the principles of good governance. First, information disclosure has a positive correlation with participation and makes public participation more substantial. Second, with the disclosure of information, the level of accountability of public bodies will be maintained. Third, the implementation of the KIP Law is carried out indiscriminately. Because the truth is that information is open, and the ease of access is the right of all citizens. Fourth, the principle in public information is to make information obtained quickly, on time, at a light, and simple cost.

\section{References}

[1] The Levin Institute - The State University of New York, "What Is Globalization?" [Online]. Available: http://www.globalization101.org/what-isglobalization.

[2] G. Bertucci and A. Alberti, "Globalization and the Role of the State: Challenges and Perspectives," Reinventing Gov. Twenty-First Century, State Capacit. a Glob. Soc. DA, Cheema G. Shabbir (editors).-Westport, Connect. Kumarian Press Inc, pp. 17-31, 2003.

[3] Merriam-Webster, "Globalization." [Online]. Available: https://www.merriamwebster.com/dictionary/globalization.

[4] M. Collins, "The Pros And Cons Of Globalization." [Online]. Available: https://www.forbes.com/sites/mikecollins/2015/05/06/the-pros-and-cons-ofglobalization/\#5a68e451 ccce.

[5] L. Sheffield, J., Korotayev, A., \& Grinin, "Globalization As Link Between The Past And The Future,” J. Sheffield, A. Korotayev, L. Grinin (Eds.), Gobalization Yesterday, Today, Tomorrow (pp. XX-XXVIII). Litchf. Park Emergent Publ., 2013.

[6] A. Simmons, A. D., \& Arundel, Globalization and its Effect on National Security. Los Angeles: The Forum on Public Policy, 2006.

[7] I. Purnamasari, "Studi partisipasi masyarakat dalam perencanaan pembangunan di Kecamatan Cibadak Kabupaten Sukabumi." program Pascasarjana Universitas Diponegoro, 2008.

[8] N. Febriananingsih, "Keterbukaan informasi publik dalam pemerintahan terbuka menuju tata pemerintahan yang baik," J. Rechts Vinding Media Pembin. Huk. Nas., vol. 1, no. 1, pp. 135-156, 2012.

[9] A. Zayyadi, "Good Governance Dalam Perspektif Ushul Fiqh Kontemporer," J. Stis, pp. 4-5, 2017.

[10] M. Slamet, Membentuk Pola Perilaku Manusia Pembangunan. Bandung: IPB Press, 2003.

[11] H. Hikmawati, "PARTISIPASI MASYARAKAT DALAM PERUMUSAN KEBIJAKAN PUBLIK," JPP (Jurnal Polit. Profetik), vol. 1, no. 1, 2013.

[12] et al. Subagiyo, H., Prayitno, D. E., Tresya, D., Yasin, M., Basuki, W., Sudibyo, A., Anotasi Undang - Undang Nomor 14 Tahun 2008 Tentang Keterbukaan Informasi Publik. Jakarta: KIP, 
ICEL, dan Yayasan Tifa, 2009.

[13] R. M. Mihradi, Kebebasan informasi publik versus rahasia negara. Ghalia Indonesia, 2011.

[14] T. Mardikanto and P. Soebiato, Pemberdayaan masyarakat dalam perspektif kebijakan publik. Alfabeta, 2012. 